\title{
Measurement of propagating waves from local field potentials and unit activity in the cortex of human and monkey
}

\author{
Lyle E Muller ${ }^{1 * \dagger}$, Giacomo Benvenuti ${ }^{2 \dagger}$, Frédéric Chavane ${ }^{2}$, Alain Destexhe ${ }^{1}$ \\ From The Twenty Third Annual Computational Neuroscience Meeting: CNS*2014 \\ Québec City, Canada. 26-31 July 2014
}

The existence of propagating waves, either spontaneous or stimulus-evoked, in neocortex during the awake state has been a subject of recent interest $[1,2]$. Here, following work done previously in voltage-sensitive dye imaging of the primary visual cortex in the awake monkey [3], we apply an analysis method for non-parametric, automated detection of propagating waves in noisy multichannel data to multielectrode array (MEA) recordings taken from the neocortex of the human (middle temporal gyrus, as studied in [4]) and monkey (primary visual cortex).

In the spontaneous awake state, we detect transient, intermittent propagations occurring in the local field potential (LFP) across a wide frequency range. After selecting the propagation epochs within the highest confidence interval, we observe that the speed distribution falls naturally into the range of the horizontal fibers $(0.1$ $0.5 \mathrm{~m} / \mathrm{s}$ ), suggesting a similar propagation substrate as that observed previously in voltage-sensitive dye imaging data [3]. With this in mind, we go on to compare the spatiotemporal dynamics on the array across various states of arousal.

One question raised by our earlier VSD analysis is the extent to which the wave evoked by a small visual stimulus is supra- or sub-threshold. Specifically, because neurons during awake, "activated" cortical states sit a few millivolts below threshold $[5,6]$, operating in a fluctuation-driven regime [7], the transient depolarization detected in the VSD signal as the wave passes may change the background spiking probability in the local circuit. To address this, we analyzed the relationship

\footnotetext{
* Correspondence: muller@unic.cnrs-giff.fr

† Contributed equally

'Unité des Neurosciences, Information et Complexité (UNIC), CNRS Gif-surYvette, 91198, France

Full list of author information is available at the end of the article
}

between single- and multi-unit activity (SUA/MUA) and LFP. We study the spatiotemporal dynamics of this relationship to determine the coupling of spiking activity with transient propagating waves, and compare the results with computational models of spiking neurons.

In conclusion, we show here that a combination of multi-electrode recordings, time-series analysis, and computational modeling provides a powerful set of tools for quantifying spatiotemporal dynamics in awake states.

\section{Acknowledgements \\ The authors wish to acknowledge the aid of Sonja Grün (Jülich University), who kindly made available a Blackrock system that was used to collect preliminary results in the primate. Work supported by CNRS, the ANR (Complex-V1) and the EU (BrainScales and the Human Brain Project). LM was supported by a PhD fellowship from the École des Neurosciences de Paris (ENP).}

\section{Authors' details}

${ }^{1}$ Unité des Neurosciences, Information et Complexité (UNIC), CNRS Gif-surYvette, 91198, France. ${ }^{2}$ Insitut de Neurosciences de la Timone (INT), Marseille, 13005, France.

Published: 21 July 2014

\section{References}

1. Ray S, Maunsell JH: Network rhythms influence the relationship between spike-triggered local field potential and functional connectivity. J Neurosci 2011, 31:12674-12682.

2. Nauhaus I, Busse L, Ringrach DL, Carandini M: Robustness of traveling waves in ongoing activity of visual cortex. J Neurosci 2012, 32:3088-3094

3. Muller LE, Reynaud A, Chavane F, Destexhe A: Propagating waves structure spatiotemporal activity in visual cortex of the awake monkey. BMC Neurosci 2013, 14:08.

4. Peyrache A, Dehghani N, Eskandar EN, Madsen JR, Anderson WS, Donoghue JS, Hochberg LR, Halgren E, Cash SS, Destexhe A: Spatiotemporal dynamics of neocortical excitation and inhibition during human sleep. Proc Natl Acad Sci USA 2012, 109:1731-1736.

5. Destexhe A, Rudolph M, Paré D: The high-conductance state of neocortical neurons in vivo. Nat Rev Neurosci 2003, 4:739-751.

6. Poulet JFA, Petersen $\mathrm{CCH}$ : Internal brain state regulates membrane potential synchrony in barrel cortex of behaving mice. Nature 2008, 454:881-885. 
7. Kuhn A, Aertsen $A$, Rotter $S$ : Neuronal integration of synaptic input in the fluctuation-driven regime. J Neurosci 2004, 24:2345-2356.

doi:10.1186/1471-2202-15-S1-P174

Cite this article as: Muller et al:: Measurement of propagating waves

from local field potentials and unit activity in the cortex of human and monkey. BMC Neuroscience 2014 15(Suppl 1):P174.

Submit your next manuscript to BioMed Central and take full advantage of:

- Convenient online submission

- Thorough peer review

- No space constraints or color figure charges

- Immediate publication on acceptance

- Inclusion in PubMed, CAS, Scopus and Google Scholar

- Research which is freely available for redistribution

Submit your manuscript at www.biomedcentral.com/submit

() BioMed Central 